\title{
Dare to Compare: The Comparative Philosophy of Mou Zongsan
}

Xiaofei Tu

A ll forms of piety meet in a faraway land. - Tang Junyi

$\mathrm{N}$ ew Confucianism is comparative philosophy par excellence. It stands or falls with the validity of the comparisons its thinkers have made regarding Western and Asian religious and philosophical systems and conceptions. Yet comparative philosophy and comparative religion in and beyond A sia have recently received criticisms. Q uestions that have been raised include: is it not a fallacy to take Asian philosophy and religion out of their historical and social contexts and to present them as unchanging entities? Are the across-space-and-time comparisons between Asian and Western philosophy and religion far-fetched and forced?

To answer these questions, this paper presents a case study of comparative philosophy: Mou Zongsan's post-Kantian Confucian metaphysics. After showcasing Mou, in the second part of this paper I shall consider the validity of comparative philosophy in general and the implications to my appraisal of Mou in particular.

\section{Mou's Post-Kantian Confucian Metaphysics}

Mou Zongsan's philosophy draws inspiration from, among others, The D octrine of the Mean, a Confucian classic that is traditionally believed to have been authored by Confucius' grandson Zisi. ${ }^{1}$ The importance of this ancient text lies in its articulation of what is lacking in other early Confucian classics such as the A nalects, and what Confucius "rarely talked about" - the Way of Heaven ${ }^{2}$ and the nature of man. The text boldly affirms the homology between the Heavenly and human worlds. The origin of human nature is

${ }^{1}$ Mou draws a wide variety of sources from Western and Chinese traditions. In this paper, I shall focus on his discussion of Kant and Confucianism, without getting into some other important aspects of Mou's thought, e.g. Mou's discussion of Tiantai Buddhism.

2 The concept of 天 (Heaven) had gone through certain metamorphosis in Confucianism. For Mou Zongsan and his Song-Ming predecessors, Heaven refers to the impersonal transcendent power that is aligned with moral order but dependent upon human agents to actualize its will. See Feng Youlan, A H istory of Chinese Philosophy (Princeton: Princeton University Press, 1983); also see "Confucius," in Stanford Encydopedia of Philosophy <http:/ / plato.stanford.edu/ entries/ confucius/ >. 
traced to Heaven, while the concrete form of the Heavenly Way is embodied in humans. Next, the text continues to stipulate that the contact point between Heaven and humanity is the human Mind. ${ }^{3}$ Twentieth century Confucian scholars have interpreted the Heaven-human relationship described in the Dotrine of the Mean as a presentation of the religious aspect of Confucianism. Mou Zongsan believes that the religiosity of Confucianism takes the form of "transcendence in immanence." 4 Being "immanent," the Heavenly Way resides in humanity; being "transcendent," the Way at the same time points to something bigger and greater. For Mou, the transcendence in Judeo-Christian tradition is external and remote; in contrast, the Confucian transcendence is both beyond and within this very humanity. This apparent paradox indicates that for Confucianism humanity does not refer to human existence as it is, but what it ought to be. Indeed, the Confucians contend that in its authentic form humanity is perfected morality. We hasten to add that this morality is not limited in the mundane realm; rather it is in accordance with the Way of Heaven because it is "imparted" thereby. The Confucian claim is that humanity and Heaven are united by way of their mutually shared nature. Thus humanity is grounded in a transcendent source; at the same time, Heaven comes close to us with a human and humane dimension. This unity is traditionally called the harmony of Heavenly and human virtues.

As a thinker trying to revitalize Confucianism for the modern time, Mou Zongsan is especially concerned with testing and retooling traditional Confucian concepts with the help of Western philosophy. On the one hand, he defends the Heaven-human relation as elaborated in theDotrine of the Mean On the other hand, he attempts to reappropriate this time-honored ideal in a form that is relevant to the life and thinking of contemporary people. For this purpose, Mou recasts the traditional Confucian discourse in Western ontological terms.

According to Mou, the difference between ancient Chinese and Western traditions is that the West first sought "the ultimate being" in either nature or God, while the Chinese looked for it in the Mind (xin), which is understood as the spiritual aspect of human existence that synthesizes cognitive, emotional, and most importantly, moral faculties. ${ }^{5}$ The Mind is the "locale" where the world of human spirit and values unfold. In this world of spirit and values, morality is prioritized. Indeed, a distinct characteristic of Mou's thought is his emphasis on the ontological meaning of morality. To this end, he distinguishes between "metaphysics of morals" and "moral metaphysics." While the former investigates the nature of morality and corresponds to what is usually termed meta-ethics in the West, the latter is concerned with a metaphysical system that is founded on a unique Confucian understanding of morality. Mou concedes that traditionally Chinese

\footnotetext{
4 Ihid

4 Mou Zongsan, 中國哲學的特質 [The Charadeistics of Chinese Philospophy] (臺北：臺灣學生書局, 1974), 30-31.

${ }^{5}$ Mou Zongsan, 圆善论 [On Pefeet Good] (臺北：臺灣學生書局, 1985), 255.
} 
philosophy had mostly been metaphysics of morals, i.e., ethics, but he believes that it is possible and necessary for himself to secure a place for morality in ontology. 6

For Mou, the Mind is primarily understood as moral selfconsciousness. However, it has multiple levels of meaning to be explored. First of all, it is the self-directing and self-affirming activity that is present in humanity's moral praxis. At this level, it comprises moral intentions, decisions and actions. On a second level, this Mind as moral self-consciousness is recognized as the essence and nature of all human beings; as such, it is "wired" to Heaven as the D octrine of the M ean dictates. Finally, -- and this is of pivotal importance for us to understand the uniqueness of Mou's thought -- the Mind is perceived as creating the "outside world." The words "outside world" are put in quotation marks because indeed nothing can elude the orbit of the allencompassing Mind. It is worth pointing out here that Mou is not advocating an epistemological solipsism, alleging that nothing exists but the individual human mind. Indeed, epistemology has never been a major concern for the Confucians, Mou included. The Confucians discuss Heaven and humanity for the sake of providing an anchorage for human morality, not for pure epistemological purposes. What Mou means by saying that the Mind creates is that this Mind imposes moral meanings and moral relations onto the world it touches and therefore transforms it into a human world. ${ }^{7}$

In an attempt to reappropriate Confucianism and to position it as a part of world philosophy, Mou incorporates Western philosophical perspectives on this issue and selects Kant as his dialogue partner. In fact, unlike such German philosophers as Leibniz and Christian Wolff, Kant does not hold Chinese thought in very high regard. ${ }^{8}$ The reason for Mou's selection of Kant lies in Mou's belief that Kant represents the "modern" philosophy in the spirit of the Enlightenment epoch. Mou's intention is for Confucianism to speak to modernity.

More specifically, Mou is impressed by Kant's affirmation of the absoluteness of moral imperatives, and the Kantian effort to reach the transcendent via practical reason, in which Mou sees parallels to the Confucian tradition that highlights the unity between Heaven and humanity. ${ }^{9}$ Nevertheless, Mou contends that despite his worthy intent, Kant was not

\footnotetext{
6 Mou Zonsan, 現象與物自身 [Phenomenon and N oumenon] (臺北：臺灣學生書局, 1975), 39.

7 Mou Zongsan，智的直覺與中國哲學 [Intuitive Understanding and Chinese Philosophy] (臺北市：臺灣商務印書館, 1971), 190-191.

${ }^{8}$ Leibniz saw an affinity between medieval Confucianism and his own philosophy. Wolff was banished from Prussia partly because of his sympathy to the "atheist" Chinese thought. See Heiner Roetz, Mensch und $\mathrm{N}$ atur im alten China: zum Subjekt-O bjekt-G egensatz in der klassischen chinesichen Philosophie, zugleich eine Kritik des Klischees vom chinesischen U niversismus (Frankfurt am Main:: Peter Lang, 1984), 5-8.

${ }^{9}$ Interestingly, Mao Zedong also sees an affinity between medieval Confucianism and Kantian philosophy. Li Zehou, 中国古代思想史论 [0n A ncient Chinese Thought] (北京：人民出版社, 1985), 220.
} 
successful in reconnecting the transcendent and the immanent. Kant views the human mind only in perceptive and cognitive terms, and as such the mind is not able to reach the "Ding an sich." Kant makes the insurmountable distinction between noumenon and phenomenon, that is, that which cannot be the object of empirical knowledge and that which can. About noumenon, the only knowledge we can possibly have is the negative knowledge that it is in principle insulated from of our perception. Any attempt to gain certain knowledge about the fundamentally unknowable, is bound to fail. There is a caveat in Kant that allows noumenon to be directly realized-not as phenomenon but as itself. Such a realization is accomplished through the socalled "intuitive understanding," a capacity that belongs to God alone but is beyond the reach of human beings.

In Kantian terms, Mou believes that the Way of Heaven is a noumenon, i.e., the unobservable reality that underlies the observed phenomenon. However, he argues against Kant that this noumenon is not a lofty D ing an sich indifferent to the human world. Rather, Reality is what the Confucians traditionally called the Way of Heaven that brings moral meaning and moral values into being. Mou believes that reaching noumenon is humanly possible for the following reasons: Both Kant and Confucianism agree that moral commands are unconditional. Hence the giver of moral commands should be unconditional. Moreover, such a giver cannot be $\mathrm{G}$ od - moral laws given to humans by an $\mathrm{O}$ ther are conditioned by this $\mathrm{O}$ ther. Therefore, moral commands must be self-giving, that is, they are given by the human Mind. Since unconditional things cannot be given by something conditioned, the human Mind must be unconditional too. Since the human Mind and the Way of Heaven are both unconditional, and the ultimate unconditional being must be one and the same, as a result, the human Mind and the Way of Heaven must be identical. ${ }^{10}$ If the above argument smacks of the ontological argument of Anselm that had been criticized by Kant, we need to note that Mou philosophizes not merely to interpret Kant but to improve on and move beyond Kant. As such, Mou tries to sublate Kant and other philosophies, including the thought forms that Kant had deemed invalid. ${ }^{11}$ Moreover, Mou argues that both Heaven and the Mind are not theoretic hypotheses but a selfrevealing reality. The unity of Heaven and the Mind is existentially presented to us, closer and more true to us than any of our knowledge that we gather from our perception. ${ }^{12}$

${ }^{10}$ Mou Zongsan, 智的直覺與中國哲學 [Intuitive Understanding and Chinese Philosophy] (臺北市：臺灣商務印書館, 1971), 190ff.

${ }^{11}$ It is still an open question whether Kant had successfully dismantled the ontological argument. For a theological defense for Anselm, see e.g. Karl Barth, A nselm, Fides quaerens intellectum: A nselm's proof of the existenœ of $\mathrm{G}$ od in the context of his theological scheme (Pittsburgh: Pickwick Press, 1985). For some recent discussions see Richard Swinburne, The ex istence of G od (Oxford: Clarendon Press, 1984) and Alvin Plantinga, God and other minds: a study of the rational justification of belief in G od (Ithaca, NY: Cornell Univ. Press, 1990).

${ }^{12}$ Mou Zonsan, 現象與物自身, 70ff. 


\section{8}

DARE TO COMPARE

Based on Mou's above argument, the Mind elevated by perfect moral exertion is both human and trans-human because the Mind is radically identical with the Way of Heaven. As such, the Mind itself is noumenon, and there would be no difficulty for its self-understanding and self-realization. The problem for Mou rather lies in how it could be possible for his transcendent Mind to engage the phenomenon world. Here Mou borrows a notion from the Buddhist text "The A wak ening of Faith," that the worlds of nirvana and samsara both arise from the same original Buddha Mind. In Mou's system, the selfsame Mind is able to act in both noumenal and phenomenal spheres, but in different ways. While the Mind understands and embraces the Way of Heaven as a form of self-understanding and self-realization, for it to grapple with phenomena the Mind would have to voluntarily impose limitations on itself and thus change itself into a limited agent of intellect, with its synthetic moral character being transmuted to a purely cognitive quality. This self-restraint is not in any sense a process of degeneration but an act of "self-emptying," and a necessary step for the possibility of empirical knowledge.

\section{Dare to Compare}

What motivates Mou to engage in comparative philosophy? First of all, Mou's is a self-conscious effort to reposition their respective traditions in light of the impact of Western thought. This can be seen as part of the gigantic Asian effort at self-modernization. There is certainly dispute about the origin, nature, and outlooks of modernity and modernization. For the purpose of this paper, I consider modernity in terms of the influences from the postindustrialization European West on Asia since the nineteenth century, i.e., natural sciences; social and political systems; individualism and liberal democratic values; and a theologically sophisticated Christianity. I proceed with an awareness that both "modernity" and the "West" are not static given entities. Rather, they have multiple layers and facets; moreover, it is precisely in the interaction with the "old world" and "non-West" that they constantly assume new identities and are being redefined. Predating Edward Said, Takeuchi Yoshimi already pointed out that the European identity had been shaped by the expansion of its colonialism. ${ }^{13}$ I use these terms with the understanding that Mou deployed the ideas of modernity and West for the purpose of defining the self-identity of Chinese people and Chinese thought. ${ }^{14}$

13 Takeuchi Yoshimi, What Is Modernity? W ritings Of Takeuchi Y oshimi (New York: Columbia University Press, 2005).

${ }^{14}$ In the meantime, I do not agree with the "postmodern" claim that differences between tradition and modernity does not exist. According to the postmodernist, what exists is rather the practice of differentiation that aims at creating certain political meaning. As Ogoshi Aiko points out, "We must guard against the facile reduction of everything to cultural determinism, but the attempt to solve problems universalism without considering cultural background is also a futile play of abstractions... Unless there is a critical perspective against the existing cultural climate, Japanese style postmodernism will remain nothing more than a reactionary play of abstractions." Quoted in "A Feminist View of Maruyama Masao's 
It is against this background that I consider the comparative thought of Mou. While European philosophers and religious thinkers could proceed with their speculative enterprise without bothering with Asian thought, it was not possible for their Chinese colleagues to work without referring to European traditions. Founded on Western theoretical frameworks and conceptions, yet necessarily in constant negotiation with indigenous thought, modern Chinese philosophy became comparative in approach. As Kant is the most indispensable figure in modern philosophy, through a dialogue with him, Mou attempts to negotiate a place for Confucianism in the global gallery of ideas.

Second, Mou's comparative philosophy is motivated by his existential concerns. Borrowing from Steven Collins, by "existential" I mean "an intellectualist attempt to find a reflective, rationalized ordering of life, and death, as a conceptual and imaginary whole, and to prescribe some means of definitive (if only imaginatively, so far as a non-believer can tell) escaping suffering and death." 15 As Zheng Jiadong, a leading scholar of Mou, noted, Mou's existential sensitivities are particularly strong, and are rather noteworthy since a traditional Confucian is typically portrayed as being in harmony with nature and society and thus "worry free." 16 Mou's philosophical effort is not merely for speculative pleasures, but rather for the purpose of establishing a post-K antian moral subjectivity as a response to human existential conditions.

Levinas remarked that humans have two ways to access the outside world, namely, by vision and by contact. Thus in our language, we metaphorically say that we "see" or "grasp" the truth. We find an example of the philosophy of vision in Plato when he compared the human world to an arena. ${ }^{17}$ In this parable, there are three groups of people in the arena. The least worthy people are the peddlers who hawk their goods and try to make a profit. Better than the first group are the athletes competing for prizes and honor. But the worthiest among all people are the spectators who observe and reflect without participating. In real life, similarly, best people are philosophers who observe life without active participation. ${ }^{18}$ On the other hand, we could argue that Confucianism is a philosophy of contact. It is always in contact with human life and its concerns. The Confucian practitioners demand for themselves a total commitment and expected a complete intellectual and

Modernity," in Contemporary Japanese Thought, ed. by Richard F. Calichman (New York: Columbia University Press, 2005) 63.

${ }^{15}$ Steven Collins, N irvana and Other Buddhist F elicities (Cambridge: Cambridge University Press, 1998), 22.

${ }^{16}$ Zheng Jiadong, “现代新儒家的基本特征,” [Basic Characteristics of $\mathrm{N}$ ew Confucianism], in 方克立主编. 现代新儒学研究论缉, vol. 1, 70.

${ }^{17}$ Frank Thilly, A H istory of Philosophy (New York: Holt, Rinehart and Winston, 1957),

17.

${ }^{18}$ I do not intend to pigeonhole the Western philosophy as merely being observant. Pierre Hadot has pointed out that classical G reek philosophy was a way of life. It was until the time of the Roman Empire that philosophy began to become a profession of professors. See Pierre Hadot, Philosophy A s a W ay of L ife: Spriritual Ex ercises from Socrates to Foucault (New York: Blackwell Publishing Professional, 1995). 


\section{0}

DARE TO COMPARE

spiritual transformation. The goal for Confucians is "to combine the unfathomable truth with daily life." Theories that cannot be put into practice are considered a mere "play of words." Mou's philosophy with its strong existential concerns is well placed in this Confucian tradition.

Furthermore, Mou's existential concerns are complicated with the impact of Western modernization. With the dawn of modernity in A sia, the traditional value worlds were crippled, and traditional means of spiritual consolation were brought into question by the inroads of Western thought. This brought an even more acute and devastating sense of spiritual dislocation. Moreover, I argue that Mou's personal spiritual struggles were not detached from his concerns for his country and culture. A paradox exists in the core of Mou's philosophy: following the Confucian tradition, Mou believed that philosophy should be carried out "for the sake of oneself," that is, for one's own moral perfection. Borrowing Langdon G ilkey's comment on the Japanese Philosopher Nishitani Keiji, Mou's philosophy is "individualistic" in this regard. At the same time, Mou also believed that the sum total of the selfmotivated, individual effort in moral and religious self-cultivation would lead to the renewal of cultural life and the prosperity of his nation. This belief carried political implications because it diametrically opposed the vision that social betterments can be achieved only through the collective effort of education and mobilization of the masses. This belief helped explain the personal political involvement of Mou and his political philosophy vis-à-vis the surging nationalism and Marxism in 20th century Japan and China.

\section{Methodological Reflections}

Regarding the comparative method, Liang Shumin, a fellow Confucian of Mou, thought that it was a necessity to reach out to audiences from different cultures. ${ }^{19}$ He wrote,

Making an argument is different from writing poetry. Poetry expresses one's feelings, and the poet may not care about what others think about his work. Writing a book, however, is to explain to the reader something he did not have previous knowledge about. Therefore you have to try your bets to accommodate your reader. If I were to write a book on Confucianism, I would certainly begin with comparing different cultures and scholarship from all over the world. From a comparative eye, the main characteristics of each compared tradition become evident. Of course, in comparison, we first compare the

${ }^{19}$ Liang made his name and received a teaching position at the prestigious Peking University in 1917 with his scholarship in comparative study of Buddhism and Western philosophy. 
basics. Do not be afraid of being superficial, all knowledge is founded on these superficial things. ${ }^{20}$

On the other hand, other Asian scholars have also pointed out the necessity of a dialogue between Western and East Asian philosophy for the sake of A sian philosophy. Nishitani remarked that he was happy about the fact that contemporary Japanese culture had been influenced by Western culture. Eastern culture, as a living tradition, should be rethought with the help of Western philosophy. ${ }^{21}$

There have been friendly worries about the comparative method. Roger Ames praises Mou for continuing "the Confucian linage by translating and in fact transforming their strongest rival, who is by intention exclusive and imperialistic, into a vocabulary consistent with their own premises." $22 \mathrm{He}$ nevertheless worries that by overstating the similarity between Western and Asian thought, we could end up undermining Chinese philosophy as a real alternative to the Western thinking. ${ }^{23}$ At the end of the spectrum, critics of Asian philosophy such as Bernard Faure and Arif D irlik have staged attacks on the comparativists with plentitude of bias. ${ }^{24}$

It seems to me that the anti-comparatitivists are mostly positivists and sometimes influenced by Marxism. They often imply that comparatitivists are methodologically naïve in that the latter take both Asian and Western concepts at face value and readily pick up superficial similarities. Moreover, such comparisons, by focusing on the world of ideas stripped of social and political realities, ideologically reinforces the status quo. According to these critics, the methodologically "sophisticated" anti-comparatitivists would rescue Asian thought from shrouds of myth and ideology and restore the real, historical facts about those traditions. Part of this methodological haughtiness seems to me a twisted and disguised form of Eurocentricism. Nishitani observed that Christianity propagated a totally undeserved divine love, by virtue of which the Christian "sinners" became the holders of an absolute religion. Similarly, today's Marxism and some forms of Marxism-influenced "progressive" thought style themselves as critics of Western military and cultural imperialism, as well as critics of unjust social reality. By virtue of their claims to being "critical" and ideology-free, they give themselves a privileged position. Ironically, some of the American and European academics who most indignantly denounce the Western hegemony in reality piggyback on the very dominance they attack, benefiting from the prestige that Western scholarship

${ }^{20}$ Liang Shuming, 梁漱溟全集 [Complete W orks] (济南: 山东人民出版社，1989), 753.

${ }^{21}$ Nishitani Keiji, "Encounter with Emptiness," in The Religious Philosophy of N ishitani Keiji, ed. by Taitesu Unno (Berkeley, CA: Asian Humanities Press, 1989), 2.

${ }^{22}$ Roger Ames, "New Confucianism," in Chinese Political Culture, ed. by Shiping Hua (London: M.E. Sharpe, 2001), 84.

${ }^{23}$ Ibid., 94.

24 See e.g. Arif D irlik, "Postmodernism and Chinese History," in boundary 2, $28: 3$ (2001) and Bernard Faure, "The Kyoto School and Reverse Orientalism," in Japan in Traditional and Postmodern Perspectives (Albany, N ew Y ork: State University of N ew York Press, 1995). 


\section{DARE TO COMPARE}

enjoys in, and the huge advantage of the Western academic industry over, the rest of the world.

Most recently, we have witnessed in some scholars the drive to deconstruct and to debunk, which is, of course, by no means limited in the field of Asian philosophy. ${ }^{25}$ The relevance of this deconstruction fever to comparative studies is that such deconstruction supposedly pulls the ground under the comparative approach. A comparison of two "manufactured" systems is unwarranted and even ludicrous - in Buddhist terms, "a dream in dreams." The positivistic tendency, not only snobs at received history and traditions, but goes to the extreme view that whatever is not preserved in existent writings or inscriptions, did not happen at all. This calls to mind the King Milinda's questions to Nagasena:

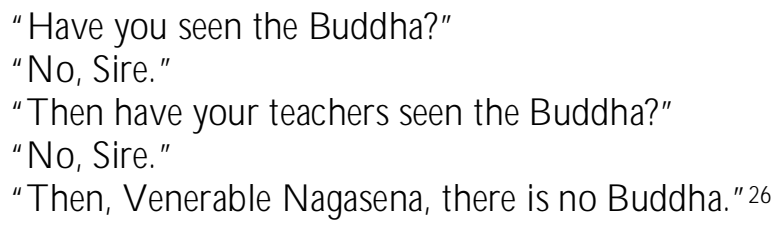

This radical positivism is self-defeating, because with good and not so good reasons, this same approach has called into suspicion all evidence that we have in hand and thereby created a vacuum for all people including themselves. They pull the ground underneath everybody, and lose a place for themselves to stand on. The philosopher Husserl expressed his concern regarding historicism and positivism in the first half of the twentieth century: "Historicism, if pushed to its logical extreme, will become radical skepticism and subjectivism." 27 Radical skepticism, according to Wittgenstein, in addition to be logically self-defeating, "is a sign of a kind of deadening of the world, an unwillingness to allow things to speak to us as well as a denial of our need to listen." 28

Robert Segal has summarized the "sins" of the comparative method. It has been criticized

1) for finding only similarities among phenomena and ignoring differences;

2) for confusing similarity with identity;

25 See e.g. Lionel Jensen, Manufacturing Confucianism: Chinese Traditions and Universal Civilization (Duke University Press, 1997) and Bruce Brooks, The Original A nalects (Columbia University Press, 2001).

${ }^{26}$ The Q uestions of King Milinda, part 1, trans by T. W. Rhys Davids, in Sacred Books of the E ast, vol. XXXV (Oxford: Clarendon Press, 1890), reprinted by D over Publications (New York, 1963), 109.

${ }^{27}$ Edmund Husserl, Philosophie als strenge W issenschaft (Hg. Von Wilhelm Szilasi, Frankfurt am Main: Klostermann, 1965), 51.

${ }^{28}$ Edward Minar, "Heidegger, Wittgenstein, and Skepticism," in The H arvard Review of Philosophy, IX (2001), 37. 


\section{3) for generalizing too broadly; \\ 4) for generalizing prematurely; \\ 5) for taking phenomena out of context; \\ 6) for generalizing at all.}

Not believing these charges against the comparative method, Segal counters that first, it is not self evident why differences are more important than similarities; and why the purpose of scholarly endeavor should be uncovering the "uniqueness" of each object of study rather than "general rules" that could explain a whole range of phenomena. Second, two objects by logic are different, the identifying of two objects in comparison would rarely, if ever, happen. Third, there are only right and wrong comparisons, not broad and narrow ones, the scope of comparison is decided by its aim. Fourth, comparisons are always provisional, not conclusive, just as in any other methods. Fifth, what might seem to be taking phenomena out of context is in fact selectiveness. And again, selectiveness is present in comparative as well as any other methods. Hence Segal contends that comparison is not only permissible but indispensable. "To understand any phenomenon, however specific, is to identify it and to account for it. To identify something is to place it in a category, and to account for it is to account for the category of which it is a member. Both procedures are thus inescapably comparativist." 29 Indeed, the mistakes committed by overzealous or careless comparativists should not be blamed on the comparative method itself. In Buddhist terms, any fallacy of the comparative scholars is the fallacy of practitioners, not the fallacy of the dharma. In a traditional Chinese parable, you should not stop eating and starve yourself to death just because you have been choked by food once.

In English speaking scholarly circles, comparative philosophy and comparative religion have been received with suspicion. This has been due to several reasons. First, the overgeneralizations of early Orienralists in their comparative studies have served as a cautionary tale. Then Christian theologians' and missionaries' involvement in comparative philosophy and comparative religion makes secular scholars bristle at the shadow of Christian apologetics. Also, the text-based approaches adopted in comparative philosophy have been viewed as disembodied and elitist missteps. However, these well-grounded criticisms in the Western context cannot be convincingly applied to Asian philosophy. As shown above, Asian philosophy and Mou's philosophy, in particular, have different motivations and rationales for their comparative approach. I believe such comparative philosophies are legitimate and justified.

Abandoning their own tradition in order to embrace sophisticated Western philosophy and theology was tempting for some twentieth century Chinese thinkers-especially when the material achievements of the West seemed to be validating the value of the thought and culture behind such accomplishments. But Mou was not afraid of coming to the defense of a

${ }^{29}$ Robert Segal, “In D efense of Comparative Method," in N umen, vol.48 (2001), 369. 


\section{DARE TO COMPARE}

Confucianism that had fallen from favor with many others. Mou's contribution to the age-old Heaven-human discussion is twofold. First, he attempts to offer an alternative to Western spirituality by standing firmly in line with the Confucian tradition that radically affirms the identification of Heaven and human nature. Secondly, he tests the possibility of dialogue between Chinese and Western philosophy by fashioning a Confucian moral metaphysics with integrated Western theoretical frameworks and concepts. For Mou Zongsan, the foremost significance of comparative philosophy is the acknowledgement of diversity in cultures and in human thinking. In the final analysis, the commitment to comparative studies is a mind open to new worlds and new possibilities.

Religious Studies Program, W est V irginia U niversity, U nited States

\section{References Cited}

Ames, Roger, "New Confucianism," in Shiping Hua ed., Chinese Political Culture (London: M.E. Sharpe, 2001).

Barth, Karl, A nselm, Fides Q uaerens Intellectum: A nselm's Proof of the E xistence of G od in the Contex t of $\mathrm{H}$ is Theological Scheme (Pittsburgh: Pickwick Press, 1985).

Collins, Steven, N irvana and Other Buddhist Felicities (Cambridge: Cambridge University Press, 1998).

The D octrine of the M ean, in A Source Book in Chinese Philosophy, trans. by Wing-tsit Chan (Princeton University Press, New Jersey, 1963).

Hadot, Pierre, Philosophy A s a W ay of L ife: Spriritual Exercises from Socrates to Foucault (New York: Blackwell Publishing Professional, 1995).

Husserl, Edmund, Philosophie als strenge W issenschaft (Hg. Von Wilhelm Szilasi, Frankfurt am Main: Klostermann, 1965).

Li Zehou, 中国古代思想史论 [0 n A ncient Chinese Thought] (北京:人民出版社， 1985).

Liang Shuming, 梁漱溟全集 [Complete W orks] （济南: 山东人民出版社, 1989).

Minar, Edward, "Heidegger, Wittgenstein, and Skepticism," in The Harvard Review of Philosophy, IX (2001).

Mou Zongsan, 中国哲学的特质 [The Characteristics of C hinese Philosophy] (台湾: 学生书局, 1974).

，智的直覺與中國哲學 [Intuitive Understanding and Chinese Philosophy] (臺北市: 臺灣商務印書館, 1971).

現象與物自身 [Phenomenon and N oumenon]

(臺北: 臺灣學生書局, 1975). ，圆善论 [0 n Perfect G oodness] (臺北: 臺灣學生書局, 1985).

Ogoshi, Aiko, "A Feminist View of Maruyama Masao's Modernity," in Contemporary Japanese Thought, ed. by Richard F. Calichman (New York: Columbia University Press, 2005). 
Olson, Carl, Zen and the A rt of Postmodern Philosophy: Two Paths of Liberation from the Representational mode of Thinking (New York: State University of New York Press, 2000).

Plantinga, Alvin, G od and Other Minds: A Study of the Rational Justification of Belief in G od (Ithaca, NY: Cornell Univ. Press, 1990).

Roetz, Heiner, $\mathrm{M}$ ensch und $\mathrm{N}$ atur im alten China: zum Subjekt- $\mathrm{O}$ bjekt-G egensatz in der klassischen chinesichen Philosophie, zugleich eine Kritik des Klischees vom chinesischen U niversismus (Frankfurt am Main:: Peter Lang, 1984).

Segal, Robert, "In D efense of Comparative Method," in N umen, vol.48 (2001).

Swinburne, Richard, The E x istenœ of $\mathrm{G}$ od (O xford: Clarendon Press, 1984).

Takeuchi, Yoshimi, W hat Is M odernity? W ritings Of Tak euchi Y oshimi (New Y ork: Columbia University Press, 2005).

Thilly, Frank, A H istory of Philosophy (New York: Holt, Rinehart and Winston, 1957).

The Q uestions of King Milinda, part 1,trans. by T. W. Rhys Davids, in Sacred Books of the E ast, vol. XXXV (Oxford: Clarendon Press, 1890; reprinted by D over Publications, New Y ork, 1963).

Youlan, Feng, A H istory of Chinese Philosophy (Princeton: Princeton University Press, 1983).

Zheng Jiadong, “现代新儒家的基本特征” [Basic Characteristics of New Confucianism], in 方克立主编. 现代新儒学研究论缉, vol. 1. 